\title{
URBAN STUDENTS' READING COMPREHENSION ACHIEVEMENT: IMPLICATIONS OF ATTITUDE, MOTIVATION, AND PARENTAL INVOLVEMENT
}

\author{
Welly Ardiansyah $^{1}$, Murwani Ujihanti ${ }^{2}$, Nurul Aryanti ${ }^{3}$ \\ ${ }^{1,2,3}$ English Department, Politeknik Negeri Sriwijaya, Indonesia \\ Corresponding author's e-mail: ardiansyahwelly@gmail.com
}

\begin{abstract}
The reason why the writers conducted the research is to know the correlations among reading attitude, and motivation of urban students, and parental involvement towards their reading comprehension achievement of four private polytechnics in Palembang 2018/2019. In conducting the research, the writers used the method of quantitative-correlation. The sample was 99 students and the random sampling method was used. All the data were analyzed with Multiple Regression. The instrument to collect data in this research is the reading comprehension test comprising 40 questions in terms of multiple choices. The results show that (1) reading attitude has a positive influence towards reading comprehension achievement in which $t 1=2.596, p$-value = $0.011 / 2=0.0055<0.05$, (2) reading motivation has a positive influence towards reading comprehension achievement in which $t 2=4.658$, p-value $=0.000 / 2=0<0.05$, (3) parental involvement significantly influences students' reading comprehension achievement in which $t 3=6.21$, p-value $=0.000 / 2=0<$ 0.05, and (4) FCal is 31.189, p-value $=0.000<0.05$ which imply that students' reading attitude, students' reading motivation, and parental involvement positively affect students' reading comprehension achievement.
\end{abstract}

Keywords: attitude of reading; reading motivation; parental involvement; reading comprehension achievement

\section{INTRODUCTION}

Globalization has integrated the world into one space without barriers of national borders. The internet and information technologies in this age rapidly develop so fast and successfully have changed the mindset of students. Most of the students lost their willingness in reading, besides reading will facilitate them in the learning process. They spend more their time with smartphones and are not willing to read their reading materials however they aware of the usefulness of reading. Eight million students are reading at a basic level of proficiency. The workforce demands of the 21st century require an advanced set of literacy skills that many of the nation's students are not prepared to meet or compete in today's rapidly changing global economy (Malik, 2018). This fact is so alarming since the modern global economy does not pay students for what they know because the internet knows everything. The world economy pays students for what they can do with what they know. Nations that want must invest to produce students who know how creatively they can use what they know and apply their knowledge in another context (OECD/EU, 2018). To conclude, students who are best prepared for the future are change agents. They can have a positive impact on their surroundings, and influence the future.

To succeed in this new global age, our students will need the capacity of reading 
(Jacobs, 2013). Motivation and attitudes towards reading play a prominent role in reading. Students who read more frequently and who feel confident in their reading abilities summarize a text or search for information on the internet, tend to be more proficient in reading (OECD, 2018). Parental involvement greatly impacts a student's learning and literacy experiences. It not only affects students' achievement positively but it also develops cognitive and social development, positive attitudes and behaviors, good personality, and potential skill into the higher education settings (Durisic \& Bunijevac, 2017). To conclude, the combinations among motivation and attitudes towards reading, and parental involvement increased students' academic achievement.

School location is a determining factor that may affect students' attitudes, motivation, and academic achievement. Factors like teachers' qualifications, availability of instructional materials, well-equipped laboratory, and workshops amongst others may also influence the urban students' performance (Iserameiya \& Uwameiya, 2018).

Research concerning the effects of location in school performance and improvement conducted by Reeves and Bylund (2005) showed that students' reading scores are much better than in rural areas over five years, scoring about 4-7 points higher. Another research conducted by Yoder (2008) showed that urban students outperformed rural students on the SAT, scoring nearly 13 to 16 points higher. Those with a higher SAT score had a significantly greater chance of being admitted to the university (Manley, 2018).

A better understanding of written texts will be much better in case there is a cooperation between students and their parents. Students must be able to elevate and improve their reading attitude and motivation, and parents must involve themselves in their children's learning process at home. Thus, this study is concerned with an investigation of urban students' reading attitudes, and students' reading motivation, and parental involvement towards students' reading comprehension achievement.

\section{Attitudes towards Reading}

In any endeavor, the core of everyone's success is how big, how well, and how positive a person's attitude has. To succeed in learning, every learner must have a positive attitude (Coiro, 2012). The attitude here must be manifested in a reading activity in which it makes and causes a learner to approach or avoid a reading situation (Vehovec, Zubkovic, \& Reinic, 2014).

Why is it necessary or emphasized on attitude in studying reading? It is because a 
positive attitude towards reading will affect students' reading comprehension achievement in-class reading activities and sooner or later the students are going to be independent readers.

\section{Reading Motivation}

In English foreign language learning, motivation is needed because motivation becomes one of the factors determining the success of the learner. There is a relationship between motivation and reading proficiency (Ahmadi, 2013). The results of his study indicated that reading motivation is related to all aspects of motivation and is related to reading comprehension and using strategy in different conditions. He stated that learners' motivation positively affects their reading; it means that learners with stronger reading motivation can be expected to read more in a wider range.

Reading motivation as a large amount of motivation that students have got to consider their positive or negative idea about reading. Students who read for pleasure and employ strategies to support their comprehension are highly motivated readers. Such students usually consider reading to be an important factor in their daily activities, accept challenges in the reading process, and are likely to be successful readers. Motivated students are willing to read more when they are allowed to choose their reading materials because they are going to discover that reading is an enjoyable activity.

\section{Parental Level of Education}

In every field of endeavor, parents' education is in line with students' academic achievement (Li \& Qiu, 2018). It occurs since parents at home could be the second teacher to the student in which parents can guide and counsel him to perform very well in education matters such as providing their child the necessary learning materials that the child needs to support his learning process both in school and at home.

It is believed that that parents' level of education could play an important role in determining a child's intellectual performance by motivating the intellectual potential within their children that may lead them to perform better in school and further their education in return (Alkhutaba, 2013). Students who come from an educated home would like to follow the steps of his or her family and by this, work actively in his or her studies, and usually, their educated parents support them with a good environment for academic work, enough textual and academic materials (Kainnuwa \& Mohammad Yusuf, 2013). Also educated parents deducted much time, energy, and money to help their children to perform well in academic 
activities. A parent with an educational background would be in a good position to be second teachers to their children and can guide even to counsel children on the best way to perform well in education (Norsuhaily, Ibrahim, \& Mudassir, 2017).

\section{Parental Involvement of Education}

Parental involvement in students' education is a shared responsibility, in which the school and other community agencies and organizations are committed to becoming involved in meaningful ways, and parents are committed to actively supporting their children's learning and development. Parental involvement as a factor of academic achievement demonstrates that parent involvement is positively related to expectations and importance of schooling and that by having a positive outlook toward education, a student is more likely to succeed (Porumbu \& Necsoi, 2013). Furthermore, the involvement itself not only affects students' academic matters but also students' school attendance, and behavior (Sapungan, 2015). He further says that parental involvement in education helps children to grow up to be productive, responsible members of society.

In conclusion, parents play an invaluable role in laying the foundation for their students' learning and when students are surrounded by caring, capable parents and can enjoy nurturing and moderate competitive kinship, a foundation for literacy is built with no difficulty.

\section{Parental Attitudes toward Education}

Attitude is the feeling or mental disposition of an individual that influences human behavior. The attitude towards reading is closely correlated to success in reading skills. The parental attitude can be negative or positive. The negative attitude of the parents regarding education and schooling can prevent their children from getting an education. With less parental support in schoolwork, a low level of motivation and poor self-esteem of children can result. The positive attitude of the parents can be beneficial to their children in many cases and can be reflected in the improvement in class performance, then it can create interest among children not only to learn but also to achieve higher scores in reading.

Parental attitude can be the strongest parameter of educational outcomes that a student achieves. Such a dimension is significantly related to children's motivation to learn, focus on study, do homework, master vocabulary, and conduct in a good manner. Since the parent's attitude is so important, the home and school should closely work together. Parents should make themselves partners in the education of their children, and actively support and 
continuously enrich the educational processes (Samal, 2012). In short, parents should be recognized as the major teacher of their children and the professional should be considered consultants to parents. From the above discussion, it is evident that the parents' positive attitude towards a child's education is important in determining the academic achievement of the child. The success or the failure to academic performance is determined by parental attitudes.

\section{METHODOLOGY}

A survey was developed to determine the effect if any, that students' reading attitudes and motivation, and parental involvement have on students' reading comprehension achievement. Quantitative research allows for the gathering of empirical data that can be used to calculate trends and make a graphical representation of the data to discover significant trends that may be important within the context of the study.

\section{Research Design}

This research was about multiple correlation research. The writers distributed the questionnaires of reading attitude and reading motivation, parental involvement, and reading comprehension test to know the correlations in reading comprehension to a group of students. There was no treatment or experiment on any kind of subject. After that, the writers gained the data from the tests and were analyzed to see whether students' reading attitude and motivation and parental education and involvement related to the ability to read comprehension or not. The writers used a quantitative method to analyze the result of the research.

\section{The Population and Sample of the Study}

The total number of population was 192 students of four private polytechnics in Palembang 2018/2019. There were 99 students from eight classes chosen with the random sampling method volunteered to participate in the research. The subjects were assured of the anonymity and confidentiality of their responses in the study. Of the total, 26 students were male and 73 students were female.

\section{Data Collection Instrument}

\section{Reading attitude questionnaire}

The needed data were collected through reading attitude questionnaires and targeted attitude components, that is, feeling (affective), evaluative beliefs (cognitive), and action 
readiness/behavioral response (conative). The affective component is dealing with the emotional reaction or feeling of the person toward the object of the attitude such as like or dislike. The cognitive component here refers to the ideas of the person toward the object of the attitude. While the conative component is related to behavioral reaction toward the object of the attitude. The scales consisted of five factors, namely, cognitive attitudes, conative attitudes, negative affect, anxiety, and self-assessment (Lee, 2014). Then, the students are going to rate the extent to which they agree with the statement on a 5 -point scale with $1=$ not at all true of me and $5=$ completely true of me (Keshavarz, 2011). The test reliability of the scale was 0.84 , while validity with 4.16 score.

\section{Reading motivation questionnaires}

The MREQ is a kind of close-ended questions in which the participants are not permitted to give free writing (Komiyama, 2013). MREQ was divided into two main sections about intrinsic and extrinsic motivations. The intrinsic section comprised 16 items, while the extrinsic section included 31 items. The MREQ range from "Very different from me", "A little different from me", "A little like me", and "A lot like $m e$ ".

To measure the items in the MREQ, the researchers used a four-point Likert scale (from 1 to 4). The MREQ is translated into Indonesia then the only translated MREQ is distributed to the participants to minimize misunderstanding. Also the reliability of the MREQ used was measured, and Cronbach's Alpha of each scale ranged from 0.77 to 0.88 , which is considered to be very good.

\section{Parental involvement questionnaires}

The remainder of the survey asks that participants rate, on a scale of 1-4 their level of agreement with ten statements related to their children's education. Respondents were asked to rate their agreement with ten statements concerning education using a Likert-type scale as follows: 1) Strongly Disagree, 2) Disagree, 3) Agree, and 4) Strongly Agree.

\section{Reading comprehension test}

A forty-item reading comprehension test of TOEFL was administered to make sure that there are positive correlations among students' reading attitudes, students' reading motivation, and parental involvement towards students' reading comprehension achievement. Analysis of the Data

Multiple Regression was employed in the study to examine the data obtained in terms of some variables. Data were processed using the Statistical Package for Social Sciences 
(SPSS) 24 and interpreted according to the objectives of the study.

\section{FINDING AND DISCUSSION}

Table 1. Coefficients

\begin{tabular}{|c|c|c|c|c|c|c|c|c|}
\hline \multirow[t]{2}{*}{ Model } & \multicolumn{2}{|c|}{$\begin{array}{l}\text { Unstandardized } \\
\text { Coefficients }\end{array}$} & \multirow{2}{*}{\multicolumn{2}{|c|}{$\begin{array}{c}\text { Standardized } \\
\text { Coefficients } \\
\text { Beta }\end{array}$}} & \multirow[t]{2}{*}{$\mathrm{t}$} & \multirow[t]{2}{*}{ Sig. } & \multicolumn{2}{|c|}{$\begin{array}{c}\text { Collinearity } \\
\text { Statistics }\end{array}$} \\
\hline & B & Std. Error & & & & & Tolerance & VIF \\
\hline 1 (Constant) & -64.152 & 16.015 & & & -4.006 & .000 & & \\
\hline Attitude & .268 & .103 & .209 & 2.596 & .011 & .814 & 1.228 & .268 \\
\hline Motivation & .253 & .054 & .374 & 4.658 & .000 & .822 & 1.216 & .253 \\
\hline Parental Involvement & 1.279 & .206 & .455 & 6.215 & .000 & .988 & 1.013 & 1.279 \\
\hline
\end{tabular}

Table 2. Significance Test of Multiple Regression Linearity

\begin{tabular}{lrrrrr}
\multicolumn{2}{c}{ ANOVA $^{\mathrm{b}}$} & & & & \\
\hline Model & Sum of Squares & df & Mean Square & F & Sig. \\
\hline 1 Regression Residual & 6215.368 & 3 & 2071.789 & 31.189 & $.000^{\mathrm{a}}$ \\
Total & 6310.592 & 95 & 66.427 & & \\
\hline \multicolumn{7}{l}{12525.960} & 98 & & & \\
\hline
\end{tabular}

a. Predictors: (Constant), Parental Involvement, Motivation, Attitude

b. Dependent Variable: Reading Score

Based on the table 1 of Coefficients in column $B$, the constant $b_{0}=-64.152$, regression coefficient $b_{1}=0.268, b_{2}=0.253$, and $b_{3}=1.279$. So the multiple regression of linearity is $\hat{\mathrm{Y}}=-64.152+0.268+0.253+1.279$.

Hypothesis 1

$$
\begin{aligned}
& H_{0}: \beta_{1} \leq 0 \\
& H_{1}: \beta_{1}>0
\end{aligned}
$$

Based on the presented analysis, it is obtained: $\mathrm{t}_{1}=2.596, \mathrm{p}$-value $=0.011 / 2=0.0055$ $<0.05$, or $\mathrm{H}_{0}$ is rejected. In short, it is stated that reading attitude has a positive influence on reading comprehension achievement.

Hypothesis 2

$$
\begin{aligned}
& H_{0}: \beta_{1} \leq 0 \\
& H_{1}: \beta_{1}>0
\end{aligned}
$$

Based on the presented analysis, it is obtained: $\mathrm{t}_{2}=4.658$, p-value $=0.000 / 2=0<$ 0.05 , or $\mathrm{H}_{0}$ is rejected. In short, it is stated that reading motivation has a positive influence 
on reading comprehension achievement.

Hypothesis 3

$H_{0}: \beta_{1} \leq 0$

$H_{1}: \beta_{1}>0$

Based on the presented analysis, it is obtained: $\mathrm{t}_{3}=6.21$, p-value $=0.000 / 2=0<$ 0.05 , or $\mathrm{H}_{0}$ is rejected. In short, it is stated that parental involvement has a positive influence on reading comprehension achievement.

Hypothesis 4

$H_{0}: \beta_{1}=\beta_{2}=\beta_{3}=0$, meaning those independent variables have no significant influence toward the dependent variable.

$H_{1}: \beta_{1}=\beta_{2}=\beta_{3} \neq 0$, meaning those independent variables have significant influence toward the dependent variable.

Based on the table 2 above, it is obtained that $\mathrm{F}_{\mathrm{Cal}}$ is 31.189 , p-value $=0.000<$ $0.05, \mathrm{H}_{0}$ is rejected. In short, it could be concluded that reading attitude, reading motivation, and parental involvement simultaneously affects students' reading comprehension achievement.

The strong correlations among attitude, motivation, and parental involvement towards reading comprehension achievement lead to some conclusions. The first conclusion is the classroom lecturers need to focus as much on improving attitude and motivation of their students as on direct instruction of reading comprehension techniques, and also openly involve students' parental engagement and the second is most lecturers that their students who have attitude and motivation to read will read and will most likely (or more likely) succeed in terms of comprehension. It is quite evident that the comparison of scores in this particular study reinforces the idea that students having a good attitude and motivation plus engaging their parents in the process of learning will comprehend better.

In previous researches, carried out by Saila \& Chamundeswari (2014) and [21], it has been revealed that as the levels of reading attitude, reading motivation, and parental involvement goes up, students' academic achievements also increase. Therefore, the previous findings do match up with the findings of this research. 


\section{CONCLUSION}

Based on the results of this research, it is proven that students' academic achievement is of effective partnerships with reading attitude, reading motivation, and parental involvement; therefore, attitude, motivation, and parental involvement are crucial components in educating students. Reading attitude that students possess positively contributes towards their reading comprehension achievement. In other words, the affective side of the students (attitude) is considered as one of the fundamental factors that promote and probably have big influences on the success of language learning.

Overall, parental education plays an important role in their level and quality of involvement in their children's academic development. Educated parents dominantly monitor their children's educational activities at home, try to provide cognitive enrichment around their children's environment, help their children to do homework and prepare examination, and also participate in school activities and programs.

\section{REFERENCES}

Ahmadi, M. R. (2013). The Relationship between Students' Reading Motivation and Reading Comprehension. Journal of Education and Practice, 4(18), 8-17.

Alkhutaba, A. (2013). Impact of the Economic and Social Factors on the Academic Achievement of Secondary School Students: A Case Study of Jordan. Excellence International Journal of Education and Research, 1(4), 262-272.

Coiro, J. (2012). Digital Literacies. Journal of Adolescent \& Adult Literacy, 55(7), 645-648.

Durisic, M., \& Bunijevac, M. (2017). Parental Involvement as an Important Factor for Successful Education. CEPS Journal, 7(3), 137-153.

Iserameiya, F. E., \& Uwameiya, R. (2018). Effect of Mastery Learning Strategy on Rural and Urban Students' Academic Achievement in Basic Technology in Edo State, Nigeria. World Journal of Research and Review, 6(6), 22-28.

Jacobs, H. (2013). Mastering Global Literacy, Contemporary Perspectives. New York: Solution Tree.

Kainnuwa, A., \& Mohammad Yusuf, N. B. (2013). Influence of Socio-Economic and Educational Background of parents on their Children's Education in Nigeria. International Journal of Scientific and Research Publications, 3(10), 1-8.

Keshavarz, M. H. (2011). Transfer of Reading Attitude from L1 to L2 among Iranian EFL Learners with Reference to Gender and Language Proficiency. TELL, 5(2), 61-96. 
Komiyama, R. (2013). Factors Underlying Second Language Reading Motivation of Adult EAP Students. Reading in a Foreign Language, 25(2), 149-169.

Lee, J. \&. (2014). Literate Actions, Reading Attitudes, and Reading Achievement: Interconnections across Languages for Adolescent Learners of English in Korea. The Modern Language Journal, 98, 553-573. Doi:10.1111/modl.12088

Li, Z., \& Qiu, Z. (2018). How Does Family Background Affect Children's Educational Achievement? Evidence from Contemporary China. The Journal of Chinese sociology, 5(13), 1-21.

Malik, R. S. (2018). Educational Challenges in $21^{\text {st }}$ Century and Sustainable Development. Journal of Sustainable Development Education and Research, 2(1), 9-20.

Manley, K. S. (2018). Urbanicity in Kentucky: A Study on Academic Achievement in Urban Versus Rural Students. The University of Louisville. Retrieved May 17, 2020, from https://ir.library.louisville.edu/cgi/viewcontent.cgi?article $=1216 \&$ cont ext $=$ honors.

Norsuhaily, A. B., Ibrahim, M., \& Mudassir, I. (2017). Influence of Parental Education on Academic Performance of Secondary School Students in Kuala Terengganu. International Journal of Academic Research in Business and Social Sciences, 7(8), 298-304.

OECD. (2018). PISA 2018 Reading Framework. Retrieved from https://www.oecdilibrary.org/docserver/5c07e4f1-en.pdf?expires=1590377693\&id=id\&accname $=\mathrm{g}$ uest\&checksum=82CBD5AB7016D1D76CB86BA8062356A3.

OECD/EU. (2018). The Future of Education and Skills 2030. Retrieved May 21, 2020, from https://www.oecd.org/education/2030/E2030\%20Position\%20Paper\%20(05 .04.2018).pdf

Saila, T. S., \& Chamundeswari, S. (2014). Development of Socio-Economic Background Scale. International Journal of Current Research and Academic Review, 2(12), 7883.

Samal, R. (2012). Parents' Attitude towards Schooling and Education of Children. Odisha: Department of Humanities and Social Sciences. Retrieved May Tuesday, 2020.

Sapungan, R. M. (2015). Parental Involvement in Child's Education: Importance, Barriers, and Benefits. Asian Journal of Management Sciences \& Education, 3(2), 42-48.

Vehovec, K. S., Zubkovic, B. R., \& Reinic, ,. R. (2014). Development of Metacognitive Knowledge of Reading Strategies and Attitudes toward Reading in Early Adolescence: The Effect on Reading Comprehension. Psychological Topics, 23(1), 77-08. 